\title{
アルカリ溶液中に打ける $\mathrm{Al}$ 冷間圧延板の腐食速度に 及ぼす圧下量の影響*
}

\author{
小 林 信 雄** 市之瀬 弘 之**
}

\author{
J. Japan Inst. Metals, Vol. 54, No. 11 (1990), pp. 1228-1235
}

Effect of Draught on Corrosion Rate of Cold Rolled Aluminum Sheet in Alkaline Solution*

Nobuo Kobayashi** and Hiroyuki Ichinose**

\begin{abstract}
The corrosion rate in a $0.5 \mathrm{kmol} \cdot \mathrm{m}^{-3} \mathrm{NaOH}$ aqueous solution of cold-rolled aluminum sheet was measured, and the results were analyzed from the point of view of the residual stress and rolling texture. For each total reduction (10-90\%), which was applied to cold rolling, the specimens were equalized in initial thickness. The fixed reduction rate $(\Delta h / h)$ and the fixed draught $(\Delta h)$ were applied to the reduction per pass, and the initial orientation of the specimen and the surface character of the roll were varied. In the case of the reduction rate mode applied to the reduction per pass, the corrosion rate showed a non-monotonic increase; i.e. the curve has a maxima at 30 and $80 \%$ and a minimum at $50 \%$ total reduction. Contrary to this, in the fixed draught mode the corrosion rate reached a maximum value at $30 \%$ total reduction, and then decreased non-monotonically. Regardless of the difference in initial orientation, the corrosion rate showed the same behavior, but it became smaller as the crystal grain became larger. When cold rolling was performed on rolls with a rugged surface, the rolling texture showed a surface texture $((001)[1 \overline{1} 0])$ at $90 \%$ total reduction, and there was the correlation between residual stress and corrosion rate. In the case of the fixed draught mode applied to cold rolling, the residual stress decreased and the corrosion rate became smaller in the high domain of total reduction.
\end{abstract}

(Received June 4, 1990)

Keywords: aluminum, corrosion rate, draught, residual stress, surface rolling texture

\section{I. 緒言}

Engelhardt と Gunther ${ }^{(1)}$ は $\mathrm{Al}$ に対して最終板厚を一定 にする方法を適用して冷間圧延を行い，表面集合組織 $((001)[110])$ の試料を用いて $\mathrm{HCl}$ 水溶液中に打ける腐食 挙動を調べた結果, 全圧下率の増大に対し非単調変化する ことを見出した. Dillamore と Roberts ${ }^{(2)}$ はロールと素材 間の摩擦，ロール温度，圧下量(Draught)などの因子によ る表面集合組織の形成過程を調べたが，報告された極点図 では表面集合組織は発達していない，その原因について， 上城, 関根, 久芳と竹内 ${ }^{(3)}$ は 1 回ごとの板厚減少に一定 の圧下率 $(\Delta h / h)$ を用いず，一定の圧下量 $(\Delta h)$ を加える 方式で圧延したことを指摘した。 そして，摩擦係数を大き くして 1 回の圧下率を $10 \%$ 程度で圧延すれば，全圧下率 $90 \%$ 以上のとき, 表面集合組織は最もよく発達すること を明らかにした。このように表面集合組織の形成は圧延条 件により左右され，ひいては腐食挙動にも影響することが 予想される。
著者らは，従来まで $\mathrm{Al}^{(4)}, \mathrm{Cu}^{(5)(6)}$ および $\mathrm{Zn}^{(7)}$ について 1 回ごとの板厚減少を一定の圧下率とする方式を適用して 冷間圧延を行い，各全圧下率の最終板厚を同一にした場合 の冷間圧延板の腐食試験を行って来た。これに対し，本報 では各全圧下率に対するスタート材の板厚を同一にし，1 回の板厚減少を一定にする圧下量方式を適用すると同時 に，スタート材の初期方位を変え，さらにロールの表面性 状を変えた場合についてそれぞれ冷間圧延を行い，Al圧 延板のアルカリ水溶液中に护ける腐食挙動と, 圧延条件に 基づく集合組織, 残留応力等との関係について調べ, 従来 まで行ってきた圧延方式での結果と比較検討を行った.

\section{II. 実 験 方 法}

供試材は $99.99 \% \mathrm{Al}$ 熱間圧延板である。試料の圧延方 法は, スタート材の板厚を同一にして 1 回の板厚減少に 一定の圧下量方式を採用し，圧延の際のロールの表面性状 を通常の滑らかな場合と, 粗くした場合の二通りを採用し た。

\footnotetext{
* 1989年 4 月日本金属学会春期大会に一部発表

** 大阪府立大学工学部金属工学科 (Department of Metallurgical Engineering, College of Engineering, University of Osaka Prefecture, Sakai)
} 
Table 1 Procedure for preparating initial material.

\begin{tabular}{|c|c|c|c|c|c|}
\hline Series & 1st annealing & Additional rolling & 2nd annealing & Initial orientation & ${ }^{*}$ Rolling condition \\
\hline \multirow{2}{*}{ A } & $673 \mathrm{~K}-1.8 \mathrm{ks}$ & - & - & \multirow{2}{*}{$(001)[100]+(123)[412]$} & $\mathrm{I}_{\mathrm{S}}$ \\
\hline & $723 \mathrm{~K}-1.8 \mathrm{ks}$ & - & - & & $\mathrm{II}_{\mathrm{R}}, \mathrm{II}_{\mathrm{S}}$ \\
\hline \multirow{2}{*}{ B } & $723 \mathrm{~K}-1.8 \mathrm{ks}$ & - & - & \multirow{2}{*}{ Random } & $\mathrm{I}_{\mathrm{S}}$ \\
\hline & $623 \mathrm{~K}-1.8 \mathrm{ks}$ & $10 \%$ & $723 \mathrm{~K}-1.8 \mathrm{ks}$ & & $\mathrm{II}_{\mathrm{R}}, \mathrm{II}_{\mathrm{S}}$ \\
\hline \multirow{2}{*}{$\mathrm{C}$} & $723 \mathrm{~K}-1.8 \mathrm{ks}$ & $16 \%$ & $723 \mathrm{~K}-1.8 \mathrm{ks}$ & \multirow{2}{*}{$(001)[100]$} & $\mathrm{I}_{\mathrm{S}}$ \\
\hline & $673 \mathrm{~K}-1.8 \mathrm{ks}$ & $10 \%$ & $723 \mathrm{~K}-1.8 \mathrm{ks}$ & & $\mathrm{II}_{\mathrm{R}}, \mathrm{II}_{\mathrm{S}}$ \\
\hline
\end{tabular}

${ }^{*} \mathrm{I}_{\mathrm{S}}: 10 \%$ per pass (smooth surface roll), $\mathrm{II}_{\mathrm{S}}$ : draught (smooth surface roll)

$\mathrm{II}_{\mathrm{R}}$ : draught (rough surface roll).

まず，厚さ $3.5 \mathrm{~mm}$ の供試材から圧延方向に平行に幅約 $20 \mathrm{~mm}$, 長さ約 $100 \mathrm{~mm}$ の大きさの試料を切り出した. 圧延スタート材の初期方位を変える目的で, Table 1 亿示 すような焼もどし処理を行った。 これらの処理を行ったも のを以後それぞれ A, B および C 系と呼ぶ. ここで， A 系 は加工組織の残存した方位， B, C 系は付加的圧延 ${ }^{(8)}$ を行 って, 前者はランダム方位, 後者は立方体方位を目標とし たものである．冷間圧延はスタート材の板厚の $10 \%$ (約 $0.35 \mathrm{~mm}$ ) を各回の圧下量として，10９0\%の全圧下率に 達するまで行った．Table 2 は圧延条件を示す（）内は 付加的圧延を行った場合で，＊印欄は圧下量方式を用いた 場合に対応する各回の圧下率を参考として示した．冷間圧 延には二段圧延機 (ロール：直径 $50 \mathrm{~mm}$, 長さ $70 \mathrm{~mm}$, 回転数 $18 \mathrm{r} . \mathrm{p} . \mathrm{m}$, 周速度 $\left.2.85 \mathrm{~m} \cdot \mathrm{s}^{-1}\right)$ を使用し，無潤滑で 往復圧延を行った。ロールの表面はしばしばクリーナおよ びアセトンを用いて清浄な鏡面状態にした場合(Table 1 の $\mathbb{I}_{\mathrm{S}}$ に対応) と, ロール表面に同質材の $\mathrm{Al}$ が付着した, いわゆる $\mathrm{Al}$ が焼付いた状態 (Table 1 の $\mathbb{I}_{\mathrm{R}}$ に対応) でも 行った。この場合は, 鏡面状態の場合に対し, ロールの表 面性状は見かけ上粗く，板とロール間の摩擦係数がさらに

Table 2 Condition for draught rolling.

\begin{tabular}{|c|c|c|c|c|c|}
\hline $\begin{array}{l}\text { Total } \\
\text { reduction } \\
(\%)\end{array}$ & $\begin{array}{c}\text { Initial } \\
\text { thickness } \\
(\mathrm{mm})\end{array}$ & $\underset{(\mathrm{mm})}{\text { Draught }}$ & $\begin{array}{l}\text { Rolling } \\
\text { number }\end{array}$ & $\underset{\substack{\text { Final } \\
\text { thickness }}}{(\mathrm{mm})}$ & $\begin{array}{l}\text { *One pass } \\
\text { reduction } \\
(\%)\end{array}$ \\
\hline 10 & \multirow{9}{*}{$\begin{array}{c}3.50 \\
(3.15)\end{array}$} & \multirow{9}{*}{$\begin{array}{c}0.35 \\
(0.315)\end{array}$} & 1 & $3.15(2.835)$ & 10 \\
\hline 20 & & & 2 & $2.80(2.520)$ & 11 \\
\hline 30 & & & 3 & $2.45(2.205)$ & 13 \\
\hline 40 & & & 4 & $2.10(1.890)$ & 14 \\
\hline 50 & & & 5 & $1.75(1.575)$ & 17 \\
\hline 60 & & & 6 & $1.40(1.260)$ & 20 \\
\hline 70 & & & 7 & $1.05(0.945)$ & 25 \\
\hline 80 & & & 8 & $0.70(0.630)$ & 33 \\
\hline 90 & & & 9 & $0.35(0.315)$ & 50 \\
\hline
\end{tabular}

(1) ( ): For additional rolling. (2)*: Reference.
大きい場合として取扱った。摩擦俰数を変える場合, Dillamore と Roberts ${ }^{(2)}$ はロールの表面に MgO 粉を散布 し，また，上城(3)らは熱間圧延用ロールを用いて圧延を行 っているが，本実験ではそのいずれの方法も腐食試験片表 面に影響を与えるので採用できない，その点上述の方法は 不確定ではあるが簡便で比較的影響は少ないと思われる。 焼もどし処理はすべて真空中 $(0.51 \mathrm{~Pa})$ で行った.

腐食試験は前報(4) とほぼ同様の装置を用いて, 試験片を $0.5 \mathrm{kmol} \cdot \mathrm{m}^{-3} \mathrm{NaOH}$ 水溶液中に浸漬し, 腐食の進行に伴 って発生する $\mathrm{H}_{2}$ ガスを吸引ポンプを組み合わせたロート 付きビューレット(容量 $1.0 \times 10^{-4} \mathrm{~m}^{3}$ ) の中に吸い上げた 溶液と置換捕集し， $\mathrm{H}_{2}$ ガス量の経時変化を測定する方法 で行った。腐食液は 1 回の試験に $8 \times 10^{-4} \mathrm{~m}^{3}$ を用いて $313 \mathrm{~K}$ に保った。試験片は約 $20 \mathrm{~mm} \times 50 \mathrm{~mm}$ の大きさに 切り出した冷間圧延板の一端に懸架用の穴(直径 $5 \mathrm{~mm}$ ) を 開けた後前処理を行い，さらに各全圧下率により厚さが異 なるので，腐食に対する表面積を同一にすることおよび切 断，窄孔の影響を避けるため，各試験片の下から約 40 $\mathrm{mm}$ までの圧延面を残して他のすべての部分をエポキシ樹 脂耐薬品塗料で被覆した: 表面処理はトリクレン，ベンゼ ンおよびメタノールにそれぞれ各 $300 \mathrm{~s}, 5 \mathrm{wt} \% \mathrm{NaOH}$ 水 溶液 $(288 \mathrm{~K})$ に $600 \mathrm{~s}$ 浸漬したのち, 水洗, 乾燥した。腐 食速度は試料を浸漬後 $\mathrm{H}_{2}$ ガスが $9 \times 10^{-5} \mathrm{~m}^{3}$ に達した時 点で中断 $\mathrm{L}$, 単位面積 $\left(\mathrm{m}^{2}\right) \cdot$ 単位時間 $(\mathrm{s})$ 当りの $\mathrm{H}_{2}$ ガス 発生量 $\left(\mathrm{m}^{3}\right)$ として求めた. 前報 ${ }^{(4)}$ と同様, 捕集した $\mathrm{H}_{2}$ ガ スに対する補正は行わなかった.

なお，今回の圧下量方式の試料並びに圧下率方式で最終 板厚一定の場合 ${ }^{(4)}$ と比較検討するため, 板厚は一定にして 初期方位を変えたスタート材を，1回の圧下率を $10 \%$ とし て圧下率方式で圧延した場合 (Table 1 の $\mathrm{I}_{\mathrm{S}}$ に対応) の腐 食試験も同様に行った。ただし，この場合の腐食試験に用 いたロート付きビューレットは容量 $5 \times 10^{-5} \mathrm{~m}^{3}$ のものを 用いた。

圧延板表面の残留応力掞よび集合組織における X 線回 折試験には $\mathrm{CuK} \alpha$ 線を用いた．前者の場合には測定面に (422) 面を選び平行法で $2 \theta$ を測定し, $\sin ^{2} \psi$ 法とヤング 
率 $E=67.57 \mathrm{GPa}$ ，ポアソン比 $v=0.33$ を用いてその值 を求めた ${ }^{(9)}$ 。また，後者の場合にはShulzの反射法 $\left(\alpha=90^{\circ} \sim 20^{\circ}(1.5708 \sim 0.3491 \mathrm{rad})\right)$ にり (111) 不完全極 点図を作成した.

\section{III. 実 験 結 果}

\section{1. 光学顕微鏡組織観察}

供試材の顕微鏡組織は，結晶粒が圧延方向に長く延ばさ れた加工組織であった。 $\mathrm{A}$ および $\mathrm{B}$ 系の結晶粒径は $300 \sim 500 \mu \mathrm{m}$ 程度のものが多いが，C系ではかなり大き く $1 \mathrm{~mm}$ 程度のものがみられ, 大きさとしては $\mathrm{A}<\mathrm{B}<\mathrm{C}$ の順である。これらの焼なまし材から順次冷間圧延を行っ ていくと, 各系とも全圧下率 $30 \%$ をでは殆ど粒形は変わ らず，30\%を過ぎるとやや王延方向に変形を始め，50\% では完全に元の形は崩れる. それ以後は急速に圧延方向に 引き延ばされ概ね $80 \%$ 以後は強加工組織を示す. Fig. 1 にその一例として $\mathrm{A}$ 系 $\left(\mathbb{I}_{\mathrm{R}}\right)$ の場合の圧延組織を示す.

\section{2. 腐食試験}

Fig. 2 はロール表面が鏡面状態で圧延 $\left(\Pi_{\mathrm{S}}\right)$ した試験片 の腐食速度 $(\Delta d)$ と全圧下率の関係を示す。腐食速度は,

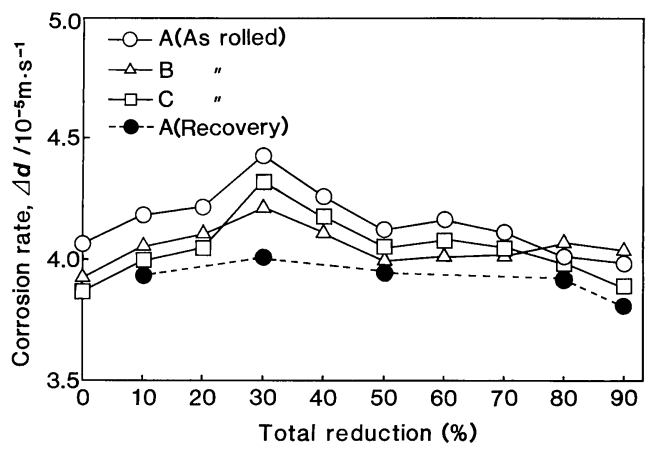

Fig. 2 Relation between corrosion rate and total reduction of as cold-rolled and its recovered $(373 \mathrm{~K}$, $1.8 \mathrm{ks}) \mathrm{II}_{\mathrm{S}}-\mathrm{A}, \mathrm{B}$ and $\mathrm{C}$ series aluminum sheets in 0.5 $\mathrm{kmol} \cdot \mathrm{m}^{-3} \mathrm{NaOH}$ solution.
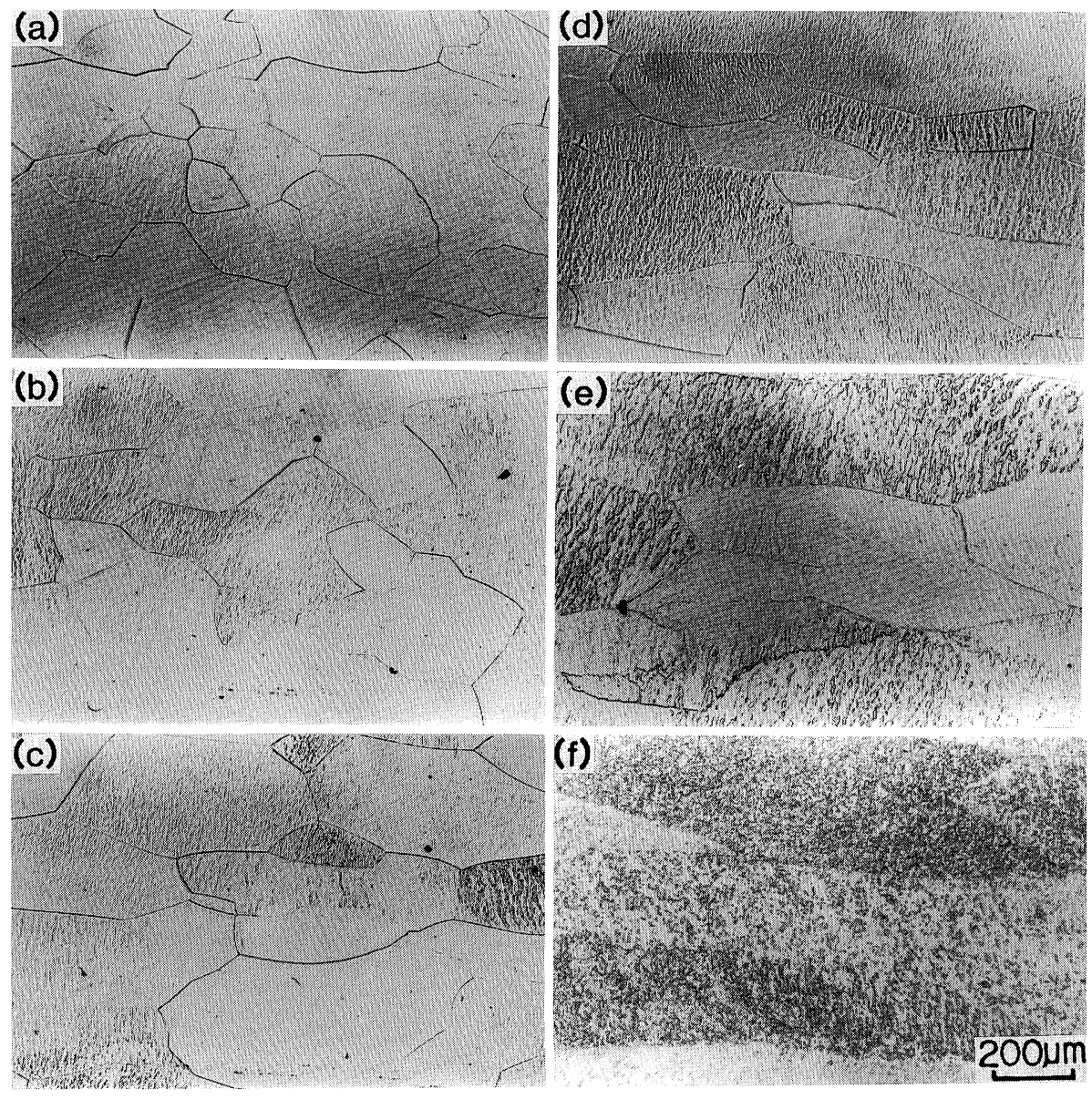

Fig. 1 Microstructures of $\Pi_{R}-A$ series aluminum specimens rolled to $10 \%$ (a), 30\% (b), 40\% (c), 50\% (d), 70\% (e) and $90 \%(f)$ total reductions. 
全圧下率30\%まで徐々に増大し，30\%を過ぎると50\%ま で急速に減少する. $50 \%$ 以後はB系を除き，Aおよび C 系は60\%までわずか増大するが，60\%を過ぎると徐々に 減少して行く傾向が見られる。B系は50\%から80\%まで 増大し90\%で減少するが，80\%の值は30\%の值よりかな り小さい。最終板厚を同一にした場合 ${ }^{(4)}$ は $50 \%$ で極小値 を示した後 $80 \%$ まで増大して，腐食速度と全圧下率の関 係が全体として非単調増加したのに対して，今回は $30 \%$ 以後は非単調減少して逆の対応をしていることが分かっ た。をた，図中の○印の曲線は，A系の冷間圧延板を $373 \mathrm{~K}$ にて $10.8 \mathrm{ks}$ 加熱して再結晶させないで回復のみさ せた試料の腐食速度を示す，回復すると圧延したままの試 料の腐食速度よりも小さくなり, 全圧下率に対して腐食速 度はほぼ一定化する傾向が見られる。これに関しては前 報(4) と同様の結果が得られた。

Fig. 3 はロールの表面性状を粗くして圧延 $\left(\Pi_{R}\right)$ した試 験片の $\mathrm{A}$ 系, $\mathrm{B}$ 系の腐食速度と全圧下率の関係を示す. A 系の場合は Fig. 2 の場合とほぼ同様の傾向を示してい る. B 系は $\mathrm{A}$ 系よりも腐食速度は小さく, それと同時に, $30 \%$ をでの腐食速度が小さく現れ，全圧下率を通じて余 り大きな差を示さなかった。しかし，曲線の傾向から本質
的にはA系と同様と考えられる。これらの原因は口ール 表面が粗いために圧延板の表面が塑性学的に不均一になっ たことに起因しているものと考えられる。 また，図中の 印はB 系の圧延材を回復させた場合の腐食速度で, Fig. 2 の場合と同様のことが言える.

Fig. 4 はスタート材の板厚を同一にして 1 回の圧下率 $10 \%$ で圧延 $\left(\mathrm{I}_{\mathrm{S}}\right)$ した場合の腐食速度と全圧下率との関倸 を示す，腐食速度は全圧下率30\%と80\%で極大を，50\% で極小值を示し，Fig. 2 および Fig. 3 の場合とは逆に全 体として非単調増加の傾向を示している．この傾向は，圧 延の最終板厚を同一にした試験片の場合 ${ }^{(4)}$ と同様の傾向を 示すことが分かった．また，腐食速度は $\mathrm{A}>\mathrm{B}>\mathrm{C}$ の順に 小さくなる。な拉，Fig. 4 に打ける腐食速度が Fig. 2, 3 に比べて小さくなっている.このことについては, Fig. 2, 3 の場合はFig. 4 の場合に用いたビューレットの 2 倍 の容量のものを使用したことにより， $\mathrm{H}_{2}$ ガスが誘導期を 過ぎて加速度的に発生する領域まで測定されたので単位時 間に対する発生量が多くなり，腐食速度は大きくなった。 それに対し，Fig. 4 の場合はその領域に達しない間に測定 が終了するので単位時間に対する発生量は少なく, 従っ て，腐食速度は小さくなったものと思われる.

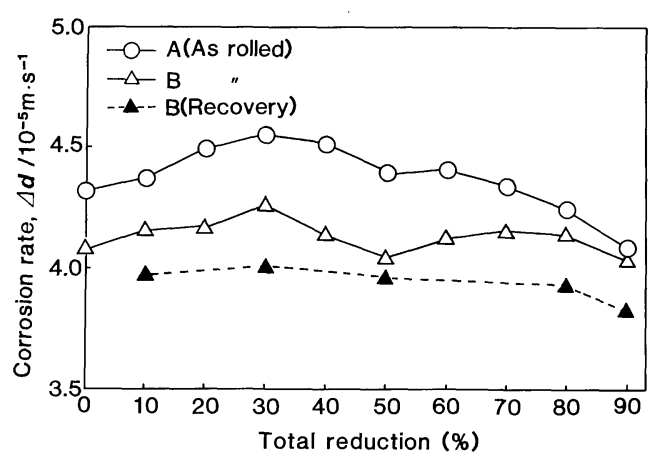

Fig. 3 Relation between corrosion rate and total reduction of as cold-rolled and its recovered $(373 \mathrm{~K}$, $18 \mathrm{ks}) \Pi_{R}-\mathrm{A}$ and $\mathrm{B}$ series aluminum sheets in 0.5 $\mathrm{kmol} \cdot \mathrm{m}^{-3} \mathrm{NaOH}$ solution.

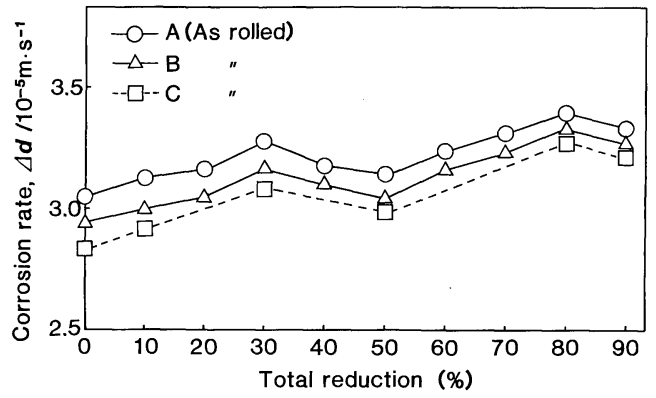

Fig. 4 Relation between corrosion rate and total reduction of cold-rolled $\mathrm{I}_{\mathrm{S}}-\mathrm{A}, \mathrm{B}$ and $\mathrm{C}$ series aluminum sheets in $0.5 \mathrm{kmol} \cdot \mathrm{m}^{-3} \mathrm{NaOH}$ solution.
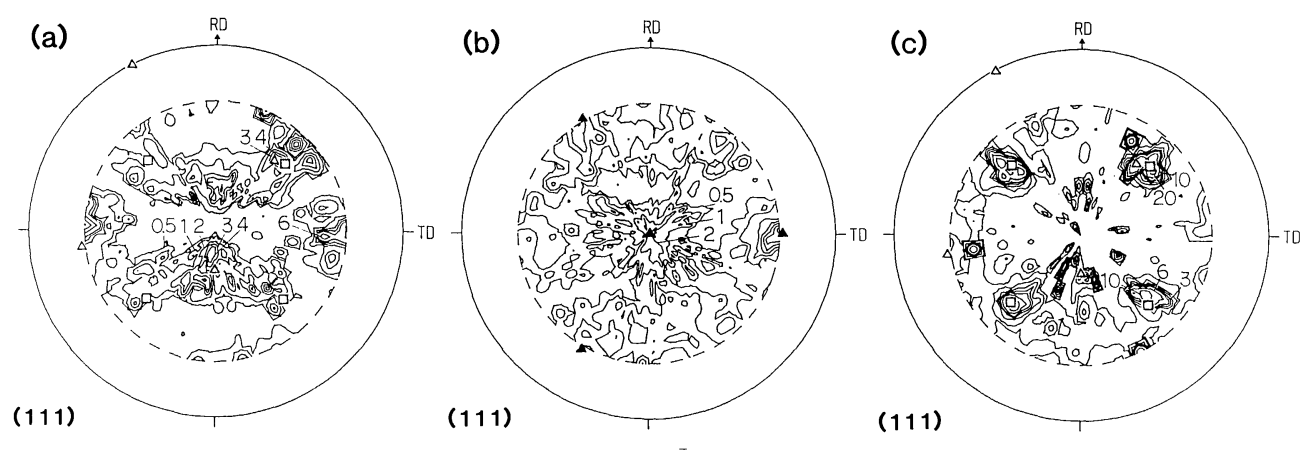

$\square(001)[100]$

$\Delta(111)[\overline{1} 10] \quad \Delta(123)[\overline{4} \overline{1} 2]$

Fig. $5\{111\}$ pole figures of initial specimens in II-A (a), B (b) and $\mathrm{C}(\mathrm{c})$ series. 


\section{3. 集合組織}

(1) スタート材の初期方位

Fig. 5 は A，B拉よびC系におけるそれぞれのスタート 材の極点図を示す．A 系は通常の加工組織が残っている 方位を目標として処理したもので，(001)[100]方位と

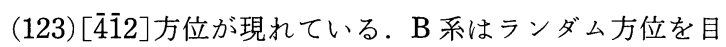
的としたものであるが，(111)[110]方位がみられ，ラン ダム方位として取扱い難いけれども，極点図全面に強度の
低い等高線が分散しているので，これをランダム方位とし た．C系は立方体方位を目標としたもので，(001) [100] 方位がかなり強く現れているが，鋭く完全なものではなく

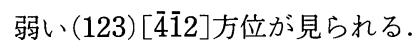

\section{(2) 冷間圧延板の集合組織}

Fig. 6(a)〜 (f) はロール表面の粗い場合 $\left(\mathbb{I}_{R}\right)$ の $\mathrm{C}$ 系に おける冷間圧延板の極点図を示す．極点図の变遷は $30 \%$ (b)からやや圧延方向へ延びる兆候が見られ，40\%(c)で は明らかに極点図の中央で連なっているのが見られる。

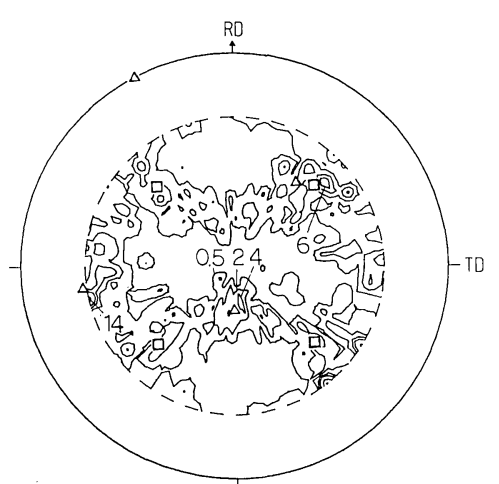

(a)

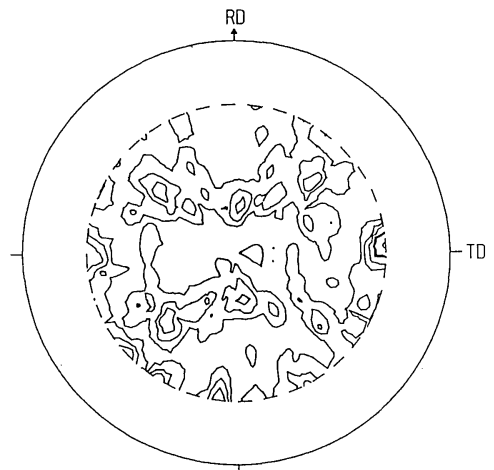

(b)

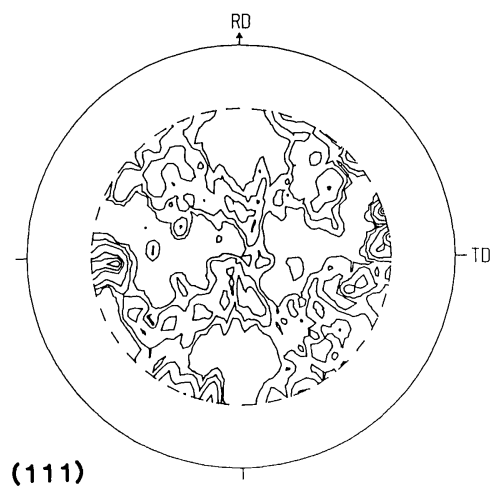

(c)

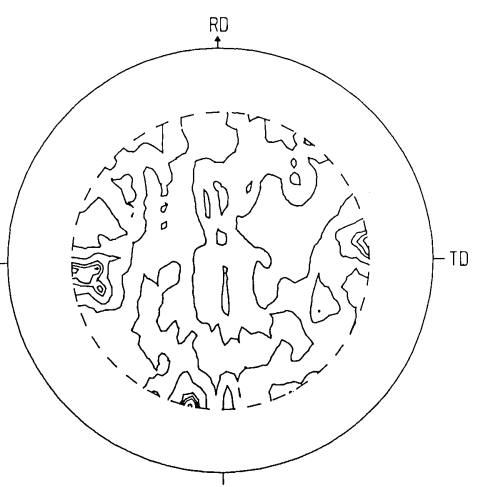

(d)

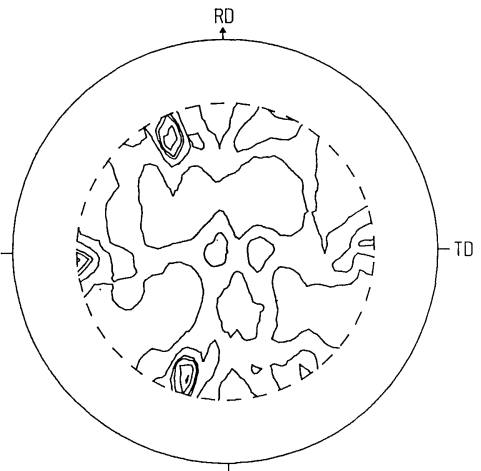

(e)

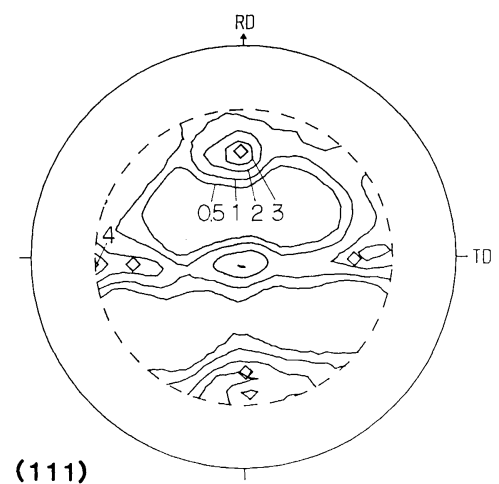

(f)

$\square(001)[100] \quad \Delta(001)[1 \overline{1} 0] \Delta(123)[\overline{4} \overline{1} 2]$

Fig. $6\{111\}$ pole figures of $\Pi_{R^{-}} \mathrm{C}$ series aluminum sheets rolled to $10 \%(\mathrm{a}), 30 \%(\mathrm{~b}), 40 \%(\mathrm{c}), 50 \%(\mathrm{~d}), 70 \%(\mathrm{e})$ and $90 \%$ (f) total reductions. 
$50 \%$ (d) 以後全圧下率の増大と共にこの傾向はさらに助長 されてせん断組織が顕著になる.70\%(e)付近から RDを 軸とした回転が起こり始め，90\%(f)では表面集合組織 (001) [110]方位が現れている. A 系およびB系について も同様に，全圧下率40\%付近から表面集合組織の形成が 始まっており，90\%ではFig. 6(f) に示したと同様の (001) [110]方位が得られた.

ロール表面の滑らかな場合のC系における冷間圧延板 $\left(\mathbb{I}_{\mathrm{S}}\right)$ の極点図は，全圧下率50\%までは純金属型集合組織 の形成過程を辿るようであるが，50\%を過ぎると TD 軸 回りに回転したよらに圧延方向に伸びる傾向を示し， 90\%では Fig. 7 (a)に示した通り，Fig. 6(d)の50\%の場合 に類似した極点図が得られた。このことから表面集合組織 形成の傾向は見られるものの $90 \%$ では完全に発達してい ないことが分かる。A系および B 系はともに $40 \%$ までは それぞれ初期方位に基づいて異なった経過を辿るが， $50 \%$ 以降は A, B および C 系とも概ね純金属型集合組織の 形成過程を辿り最終的に純金属型の圧延集合組織を示すも のと思われる。しかし，90\%においても余り鋭く発達し ない.その一例として, Fig. 7(b)にA 系 $90 \%$ の極点図を 示す.

スタート材の板厚は一定, 1 回の圧下率を $10 \%$ として, 圧下率方式で冷間圧延した場合 $\left(\mathrm{I}_{\mathrm{S}}\right)$ は，初期方位が異な る $\mathrm{A}, \mathrm{B}$ および C 系とも最終板厚を同一にした場合 ${ }^{(4)}$ とほ ぼ同様の経過を巡り，90\%では明らかに鋭い純金属型の 圧延集合組織を示す. Fig. 7 (c) は A 系 $90 \%$ の極点図を示 す.このよらに，スタート材の条件は同じでも圧下率方式 と圧下量方式では大きな差が見られた。

\section{4. 残留応力}

Fig. 8 はロール表面が粗い場合における圧延板の X 線 による残留応力と全圧下率の関係を示す. 全圧下率に対す る残留応力の傾向は Fig. 2 および 3 に示した腐食速度と 全圧下率の傾向にほぼ対応していることが分かる.

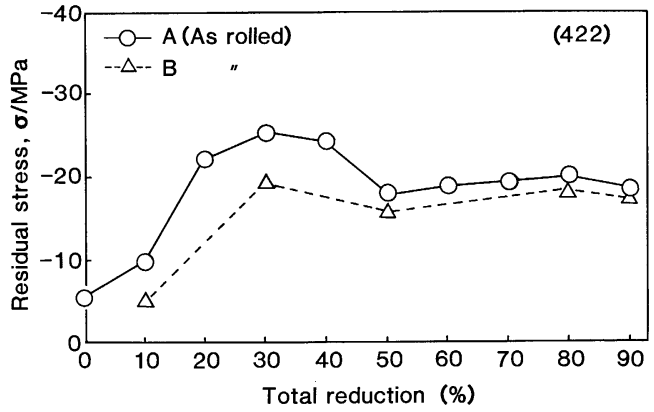

Fig. 8 Relation between residual stress and total reduction of cold-rolled $\Pi_{R^{-}}-A$ and $B$ series aluminum sheets.

\section{N. 考察}

\section{1.スタート材の集合組織が異なる場合の腐食挙動}

実験結果から分かるように，板厚は一定でそれぞれ初期 方位の異なったスタート材に対して，1回の板厚減少に圧 下率方式または圧下量方式を適用して圧延した場合，それ ぞれの圧延方式内における試料の腐食速度は，全圧下率に 対して同じ傾向を示すことが分かった(Figs. 2,3,4). ま た, 結晶粒形の全圧下率の増大に伴ら変化の仕方は, 初期 方位および圧延方式が異なっていても同様である。すなわ ら，全圧下率30\%辺りまでは焼もどし材のそれと殆ど変 わらず，30\%を過ぎると圧延方向に伸び始め，50\%では 完全に元の形は崩れる．50\%以上では急速に細長い圧延

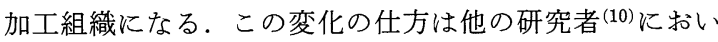
ても同様な変化の仕方が示されており，また， $\mathrm{Cu}^{(5)(6)}$ よび $\mathrm{Zn}{ }^{(7)}$ の場合でも同様のことが言え, 圧延加工と結晶 粒変形における共通性が認められる.

一方，腐食速度に及ぼす初期方位の影響は，A>B $>\mathrm{C}$ の順に腐食速度は小さくなっている。また，結晶粒の大き
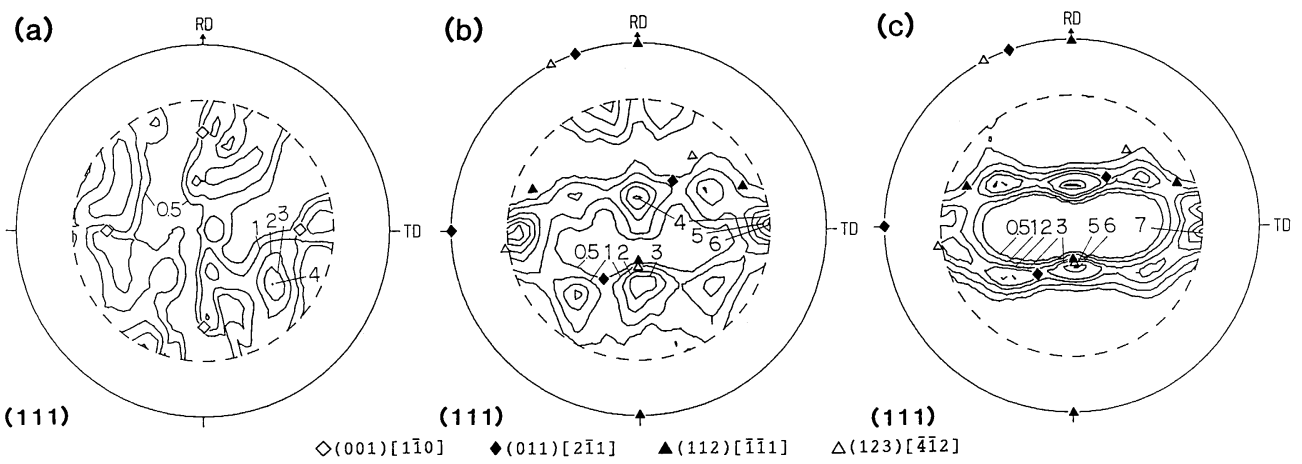

Fig. $7\{111\}$ pole figures of aluminum sheets rolled to $90 \%$ total reductions, $\Pi_{S}-C(a), I_{s}-A(b)$ and $I_{s}-A(c)$ series. 
さは $\mathrm{A}<\mathrm{B}<\mathrm{C}$ の順に大きいが，腐食速度は $\mathrm{A}>\mathrm{B}>\mathrm{C}$ の 順に結晶粒の大きいものほど小さくなっている. 初期方位 または結晶粒の大きさのいずれが腐食速度に影響を及ぼし ているか明確でないが，後述するように，結晶粒の大さい 方が粒界の拘束が少なく，したがって，ひずみによる蓄積 エネルギが小さいので，それに伴い腐食速度が小さくなる ものと考えられる.

以上のように，スタート材の初期方位が異なっていて も, 全圧下率の増大に伴う結晶粒の変形の仕方が，それぞ れの材料ともほぼ同じ傾向を示すことから，それぞれの変 形に伴うひずみエネルギの蓄積あるいは解放の変化は，最 終安定方位に達するまでに概ね同じ経過を迻るものと考え られる，換言すれば前報(4)で述べたよらに，転位の増殖， もつれに伴らひずみエネルギの蓄積および結晶のすべり回 転によるひずみエネルギ解放の様相は，それぞれの材料が 最終安定方位に到達するまでに，時期的に注ぼ同様な経過 を辿る，それに従って残留応力も同様の挙動を示し，ひい てはそれに対応した腐食速度の挙動が示されているものと 考えられる。

\section{2. 表面集合組織と腐食速度}

圧延を一定の圧下量で行った場合はロールの表面性状如 何にかかわらず腐食速度は全圧下率 $30 \%$ までは増大し， それ以後は減少することが分かった(Figs. 2,3)。ロール 表面が粗い場合は(001)[110]方位の表面集合組織が形成 されるにもかかわらず(Fig. 6)，腐食速度の挙動は表面集 合組織が形成されなかったロール表面の滑らかな場合の傾 向と同様であった，また，いずれの場合にも，回復処理に より，腐食速度が低下し，かつ全圧下率に対する依存性が ほとんど消失した。これらのことから表面集合組織そのも のが全圧下率に対する腐食速度の変化の挙動に対する影響 を与えるのではなく，むしろ後述するように残留応力の影 響が強いものと考えられる。な扣，ロール表面が粗い場合 には，滑らかな場合に比較して，腐食速度が若干高い傾向 を示したが，これは粗いロール表面に起因する圧延板表面 における不均一変形ないしそれに伴ら残留応力の発生に関 係するものと考えられる.

\section{3. 残留応力と腐食速度}

今回はロール表面を粗くした場合のみ残留応力を測定し たが，その全圧下率に対する挙動は概水腐食速度の挙動と 対応していることが分かった。

圧下量方式に打けるロール表面が滑らかな場合と粗い場 合の全圧下率に対する腐食速度 (Figs. 2, 3) 拈よび残留応 力 (Fig. 8)の曲線を, 圧下率方式の腐食速度曲線 (Fig. 4) と比較検討してみると以下のようになる，四者いずれの曲 線に拈いても，全圧下率30\%で極大值を示した後50\%ま で減少する傾向は共通している。しかし，50\%を過ぎて から $80 \%$ までの増大の仕方は，圧下率方式では $80 \%$ の值
が30\%の值よりも高いところまで増大するのに対し，圧 下量方式では増大の傾向が一部見られるものの $80 \%$ の值 は30\%の值にも達していない。そして，30\%以後の全体 を眺めた場合，全圧下率の増大と共に減少していることが 分かり，この点が大きく異なっている．このような観点か ら，圧延板表面の残留応力がその腐食速度と密接に関係し ていると推定される.この点はN.2. に打いて示した見解 と一致するものである.

圧延の方式が異なると, 上述のように全王下率50\%以 上に怙ける腐食速度の挙動が異なり，また同時に形成され る集合組織も著しく異なったものであった(Fig. 7)．上述 の観点から推定すれば，腐食速度の相違は集合組織それ自 体よりむしろ両圧延方式における変形挙動の違いに関係し ていると考えられる。すなわち，変形挙動が異なるため に，残留応力の発生状態が異なり，ひいては腐食挙動に相 違が生じたと推測される。

そこで，Fig.9に示したよらに，Table 2 および圧延機 の仕様を基に，圧下率，圧下量両圧延方式における 1 回 の圧下率打よび平均ひずみ速度を比較した。な拉，ひずみ 速度 $\left(\dot{\varepsilon}_{v}\right)$ は板厚方向の平均ロール速度成分とかみ込及前の 板厚から算出した。 また，1回の圧下率としては対数ひず みをとり，その総和 $(\Sigma \Delta \varepsilon)$ を縦軸とした。図は 1 回の圧 下で $1 つ の$ 階段の高さに相当する真ひずみを与文，その

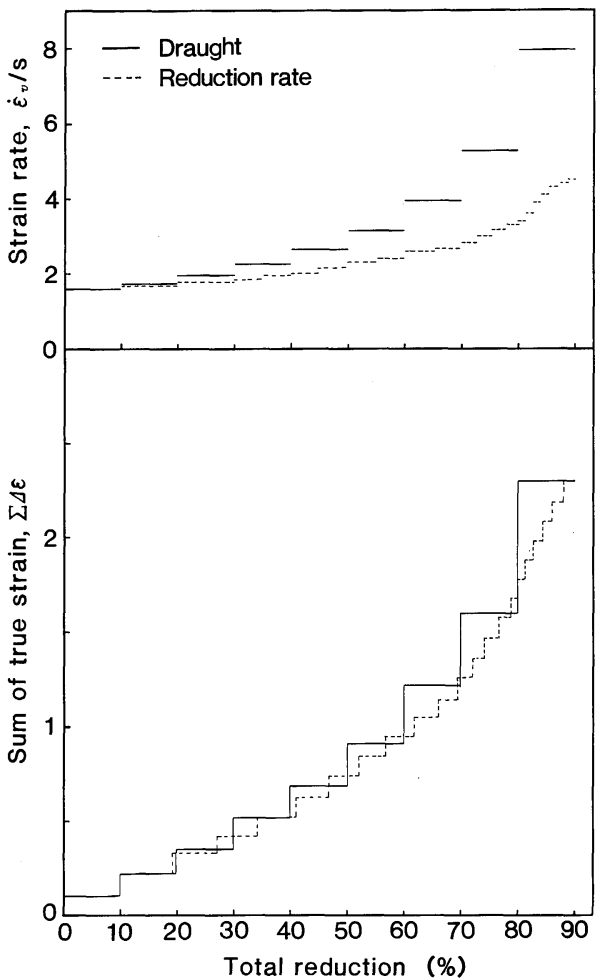

Fig. 9 Relation between total reduction and mean strain rate $\left(\dot{\varepsilon}_{v}\right)$ and sum of true strain $(\Sigma \Delta \varepsilon)$ in the draught and reduction rate rolling modes. 
結果全圧下率が階段の幅に相当する量だけ増加することを 示す。この図よりひずみ速度 $\left(\dot{\varepsilon}_{v}\right)$ およびひずみ量の総和 $(\Sigma \Delta \varepsilon)$ は, 全圧下率 $50 \%$ 程度までは, 両圧延方式で大き な差異は認め難いが，50\%を越えると，圧下量方式の圧 延では 1 回の圧下ひずみが急増する. これに伴って $\dot{\varepsilon}_{v} b$ 急速に増大寸ることが分かる．Al およびその合金の引張 試験結果からも推測されているように(11)，1回の圧延で 大きなひずみを高いひずみ速度で導入する圧下量方式の変 形においては, 変形中の動的回復と変形直後の除荷に伴ら 静的回復が著しいと考えられ, 残留応力の蓄積は次に述べ る圧下率方式の変形の場合より少ないことが期待されよ 亏.

圧下率方式の変形の場合には，比較的小さなひずみを繰 り返し与えることになるので, 動的, 静的回復は小さく抑 えられ, 結果として残留応力の蓄積が進むものと推測され る、ただし，全圧下率が $80 \%$ 程度以上では加えられたひ ずみが極めて大きいので，この変形方式においても回復の 効果が大きくなると考觉られる.

\section{V. 結 論}

冷間圧延におけるスタート材の板厚を一定にし，それぞ れ，初期方位拈よびロール表面の性状を変え，さらに，1 回の板厚減少に一定の圧下率 $(10 \%)$ と圧下量(約 0.35 $\mathrm{mm})$ の 2 方式を適用し，全圧下率10９0\%をで無潤滑で 冷間往復圧延した純度 $99.99 \%$ の $\mathrm{Al}$ 板を用い, $0.5 \mathrm{kmol}$. $\mathrm{m}^{-3} \mathrm{NaOH}$ 水溶液中で腐食試験を行った。得られた結果 について顕微鏡組織観察，X線による残留応力および集 合組織の測定結果などをもとにして次のような結論を得 た.

（1）板厚は一定でそれぞれ初期方位の異なったスタート 材に 1 回の板厚減少に圧下率を適用して圧延した場合, 腐食速度は，全珐下率30\%と80\%で極大を，50\%で極小 值を示し， $80 \%$ の値は $30 \%$ のそれよりも高く全圧下率に 対して非単調増加する。 また, 腐食速度は, スタート材の 初期方位が異なっていても，全圧下率に対して同じ傾向を 示すが，結晶粒径の大きいものほど小さくなる.

(2) 板厚は一定でそれぞれ初期方位の異なったスタート 材に 1 回の板厚減少に圧下量を適用して圧延した場合,

(a) 腐食速度は，全圧下率30\%で極大值を示した後全 圧下率の増大と共に非単調減少の傾向を示す。初期方 位が異なってもほぼ同じ傾向を示し, 結晶粒径の大き いものほぞ腐食速度は小さくなる. (b) 圧延における試料とロール間の摩擦を大きくすると (001) [110]方位の表面集合組織が形成されるが腐食 速度に対する影響は認められない。

(c) 全圧下率と残留応力の関係は, 全圧下率と腐食速度 との関係に対応している.

(d) 冷間圧延板を加熱し再結晶させないで回復のみさせ るとその腐食速度は冷間圧延板の腐食速度よりも小さ くなり，全圧下率に対して一定化される。

（3）毎回の板厚減少に圧下量を適用すると，1 回の圧延 で大きなひずみを高いひずみ速度で導入することになるの で, 変形中の動的回復之変形直後の除荷に伴う静的回復が 著しいと考えられ, 残留応力の蓄積は圧下率方式の変形の 場合より少ないことが期待される. 圧下率方式の変形の場 合には，比較的小さなひずみを繰り返し与えることになる ので, 動的, 静的回復は小さく抑えられ, 結果として残留 応力の蓄積が進さものと推測される.

終わりに, 本研究用試料を提供して頂いた昭和アルミニ ウム(秼)関係者の方々，並びに終始ご討論，ご指導を賜りま した大阪府立大学工学部金属工学科 稲数直次教授, 森井 賢二助教授，および井上博史助手の方々に深く感謝の意を 表します。また，本実験に熱心に協力された卒研生・宮島 克幸君 (現在 : 滋賀県立彦根東高等学校), 竹中健二君 (現 在 : 東洋製缶(侏) および伊藤幸洋君 (現在 : 三田工業(㭌) に 謝意を表します。

\section{文献}

(1) R. Engelhardt and F. Gunther: Metall, 24(1970), 225.

(2) I. L. Dillamore and W. T. Roberts: J. Inst. Metals, 92 (1964), 193.

（3）上城太一, 関根和喜, 久芳征一郎, 竹内敏郎：日本 金属学会誌, 36(1972), 33.

（4）小林信雄, 山崎良夫, 稲数直次 : 日本金属学会誌, 52(1988), 989.

（5）小林信雄，山崎良夫，朝倉健二：伸銅技術研究会誌, 16-1 (1977), 222.

（6）小林信雄，市之瀬弘之：日本金属学会誌，54(1990), 685.

（7）小林信雄, 山崎良夫, 稲数直次 : 日本金属学会誌, $\mathbf{5 3}(1989), 1255$

（8）高橋恒夫, 村上 雄, グェン・コン・ダン: 軽金属, 28 (1978), 35.

（9）日本材料学会編：X 線応力測定法, 養賢堂, (1971).

(10) 小泉賢一：日本金属学会誌, $\mathbf{3 2}(1968), 45$.

(11) 当摩 健, 竹内 庸 : 軽金属, $26(1976), 456$. 